\title{
Graft Application and Dexamethasone Treatment Influences New Bone Formation in Rat Tibial Bone Defects
}

\author{
Aplicación de Injerto y Tratamiento con Dexametasona Influyen en \\ la Formación de Hueso Nuevo en los Defectos en la Tibia de Rata
}

Yigit Seyhmus $^{1} \&$ Deveci Engin ${ }^{2}$

YIGIT, S. \& DEVECI, E. Graft application and dexamethasone treatment influences new bone formation in rat tibial bone defects. Int. J. Morphol., 38(5):1398-1404, 2020.

SUMMARY: The objective of this study were bone defect complications that occur due to traumas or infections. Bone grafts are required to provide support, fill gaps and improve biological repair in skeletal damage. Dexamethasone plays role in calcium signaling modulation and used in diseases. Aim of this study was to evaluate osteonectin and osteopontin expressions in new bone development after dexamethasone application on tibial bone defects. Rats were divided into defect, defect+graft and defect+graft+dexamethasone treated groups. Tibial bone defect created, and rats were kept immobile for 28 days. Alloplastic material was placed in defect area in second and group third groups. $2.5 \mathrm{mg} / \mathrm{kg}$ Dex and normal saline were injected to dexamethasone and defect groups twice a week for 56 days. Inflammation and congestion were increased in defect and defect+graft groups. Defect+graft+dexamethasone group; increased number of osteoblast and osteocyte cells, dense bone matrix, formation of new bone trabeculae was observed. Defect+graft group; osteonectin expression in graft regions, osteoblast cells, some connective tissue cells and fibers were seen whereas in defect+graft+dexamethasone group; osteopontin expression in osteoblast and osteocyte cells of new bone trabeculae were observed. Dexamethasone may lead to formation of new bone trabeculae into the graft material resulting in increased osteoconduction and osteoinductive effect for differentiation of osteon.

KEY WORDS: Bone defects; Biograft; Dexamethasone; Osteonectin; Osteopontin.

\section{INTRODUCTION}

Bone defects are complications that occur due to traumas or infections, preventing bone development (Shredah \& Abd-Nasser, 2015). While experimental animal models are mostly used to explain the molecular mechanism of defect healing, tissue engineering models have been common on new bone formation, and orthopedic surgical models on implants and biomechanical research. One of the important reasons of delays in fracture healing are implant-dependent infections. Coordination and regulation of cytokines and morphogenetic proteins play a role in fracture healing.

Bone graft use in orthopedic surgical methods is important in increasing bone regeneration. Because all the necessary features in bone regeneration are combined in terms of osteoconduction, osteoinduction and osteogenesis (Baloglu \& Deveci, 2018). Allograft is considered the best alternative to autografts and is used effectively in many clinical applications, especially in patients after fracture healing potential, non-union and established fractures. Allografts can be processed, customized, but can be found in a variety of forms, including cortical, spongy, and highly processed bone derivatives (i.e., demineralized bone matrix) (Roberts \& Rosenbaum, 2012).

Dexamethasone (Dex) is a type of corticosteroid medication that plays role in calcium signaling modulation. It is used in many diseases including arthritis, allergic disease such as asthma, croup, breathing problems, and certain cancers. It is also used to diagnose Cushing syndrome in adrenal gland. There are previous studies that show combined effects of dexamethasone and ovariectomy with osteoporosis (Weiler et al., 1995).

Bone formation is regulated by changes in extracellular matrix (ECM) and organic and inorganic composition. There are also many factors playing role in

\footnotetext{
${ }^{1}$ Department of Orthopaedic Surgery, Faculty of Medicine, Dicle University, Diyarbakır, Turkey.

${ }^{2}$ Department of Histology and Embryology, Faculty of Medicine, Dicle University, Diyarbakır, Turkey.
} 
bone formation including fibronectin, MMP family, osteoclast markers, osteopontin (OPN) and osteonectin (ON) (Dallas, 2006; Cui et al., 2011). Osteopontin, also known as bone sialoprotein 1 , is a glycoprotein found in bone matrix. It is expressed by many cell types including osteoblasts, osteocytes, macrophages, cardiac fibroblasts, odontoblasts. OPN plays role in various cellular events such as bone remodeling, maintenance of bone, immune response, apoptosis, myocardial dysfunction (Denhardt \& Noda, 1998). Osteonectin, also known as secreted protein acidic and rich in cysteine (SPARC), is acidic, cysteine-rich $40 \mathrm{kDa}$ glycoprotein. It plays role in tissue remodeling, bone mineralization, fibrosis. It is expressed by fibroblasts, chondrocytes, platelets, endothelial cells etc (Young et al., 1992). The aim of this study is to evaluate osteonectin and osteopontin expressions in new bone development after dexamethasone application on tibial bone defects in rats.

\section{MATERIAL AND METHOD}

This study was approved by the Ethics Committee for Animal Experimentation of the Faculty of Medicine at Dicle University, Turkey. Sixty male Wistar albino rats weighting 260-290 g were used in this study. Wistar Albino rats were maintained under $22 \pm 1{ }^{\circ} \mathrm{C}$ and $12 \mathrm{~h} \mathrm{light/dark}$ cycles with ad libitum access to standard pelleted food and water. All rats at the end of experiment were healthy and no difference in food/water consumption and body weight gain between experimental and control rats were observed. Every single surgical methodology and the consequent care and healing of the animals utilized as a part of this investigation were in strict compliance with the National Institutes of Health (NIH Publications No. 85-23, revised 1985) rules for animal care.

Surgical procedure of tibia bone defect. The animals were anesthetized by intraperitoneal injection $5 \mathrm{mg} / \mathrm{kg}$ of Ketamine (Ketalar®, Eczacibası, Turkey) and xylazine HCL (Rompun ${ }^{\circledR}$, Bayer, Turkey). The skin was shaved and scrubbed with an antiseptic solution (1\% iodine). After exposing the right proximal tibia of each animal, a standardized $6.0 \mathrm{~mm}$ diameter non-critical bone defect was created by using a motorized drill under irrigation with saline solution. The material used in our study was Biograft ${ }^{\circledR}$ HT (IFGL Bio Ceramics) which contains $40 \%$ b-Tri Calcium Phosphate with $60 \%$ porous biphasic synthetic Hydroxyapatite. This material is an alloplastic with granule size of $350-500 \mu \mathrm{m}$ with osteoconductive properties. So, alloplastic material (Biograft-HT®) was placed in defect area in group 2 and group 3 . Three groups (20 rats per group) were arranged as below:
1. Control group (Defect group): Tibial bone defect was created on the first day of study and rats were kept immobile for 28 days.

2. Defect + graft group: Six mm tibial bone defect with allograft treatment was applied on the first day of study and rats were kept immobile for 28 days.

3. Defect + graft + group: Alloplastic bone graft was placed in the tibial bone defect on the first day of study and Dexamethasone (Dex) treatment was applied. All rats were kept immobile for 28 days. Dexamethasone and control groups were injected intramuscularly with $2.5 \mathrm{mg} / \mathrm{kg}$ Dex and normal saline twice a week for 56 days. The dose of dexamethasone was $2.5 \mathrm{mg} / \mathrm{kg}$ (11) per day starting from the first day of study to the end. At the end of the study, animals were sacrificed by decapitation. The skin, as well as all of the soft tissues surrounding the tibia bone were removed. The samples were fixed with $10 \%$ neutral buffered formalin solution and decalcified with $5 \%$ EDTA (Ethylene diamine tetra acetic acid). After rinsing with tap water, the samples were dehydrated in increasing concentrations of ethanol and embedded in paraffin. Tissue sections of 4-6 $\mu \mathrm{m}$ thickness were prepared in the transverse plane and stained using Hematoxylin-Eosin for light microscopy examination.

Immunohistochemical studies (Fig. 1). Antigen retrieval was done in microwave (Bosch ${ }^{\circledR}, 700$ watt) for 3 min x 90 ${ }^{\circ} \mathrm{C}$. They were subjected to a heating process in a microwave oven at 700 watts in a citrate buffer $(\mathrm{pH} \mathrm{6)}$ solution for proteolysis. Sections were washed in $3 \times 5$ min PBS and incubated with hydrogen peroxide [K-40677109, 64271 Hydrogen peroxide $\left(\mathrm{H}_{2} \mathrm{O}_{2}\right)$ Dortmund, Germany, MERCK] ( $3 \mathrm{ml} 30 \%$ Hydrogen peroxide $\left(\mathrm{H}_{2} \mathrm{O}_{2}\right)+27 \mathrm{ml}$ methanol) for $20 \mathrm{~min}$. Sections were washed in $3 \times 5 \mathrm{~min}$ PBS min and blocked with Ultra V Block (lot: PHL150128, Thermo Fischer, Fremont, CA, USA) for 8 min. After draining, primary antibodies were directly applied to sections distinctly osteonectin (SPARC, catalog: 33-5500, Thermo Fischer, Fremont, CA, USA) and osteopontin monoclonal antibody (catalog no: MA5-17180, Thermo Fischer, Fremont, CA, USA). Sections were incubated and left overnight at $4 \mathrm{oC}$. Sections were washed in $3 \times 5 \mathrm{~min}$ PBS and then incubated with Biotinylated Secondary Antibody (lot: PHL150128, Thermo Fischer, Fremont, CA, USA) for 14 min. After washing with PBS, Streptavidin Peroxidase (lot: PHL150128, Thermo Fischer, Fremont, CA, USA) was applied to sections for $15 \mathrm{~min}$. Sections were washed in $3 \times 5$ min PBS and DAB (lot: HD36221, Thermo Fischer, Fremont, CA, USA) were applied to sections up to $10 \mathrm{~min}$. Slides showing reaction was stopped in PBS. Counter staining was done with Harris's Hematoxylin for $45 \mathrm{~s}$, dehydrated through 


\section{Osteonectin Expression}

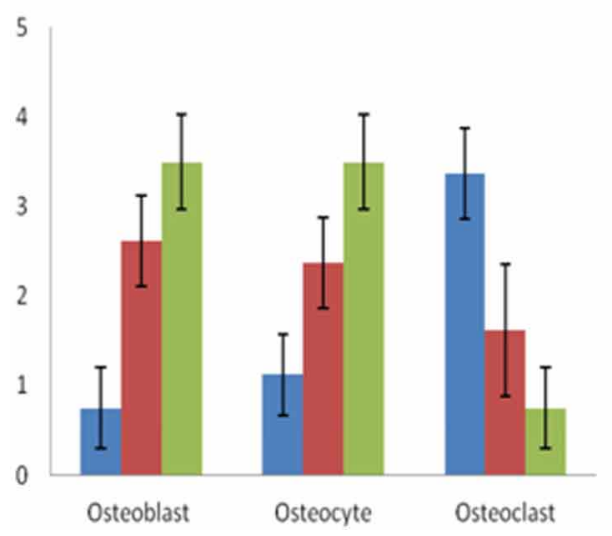

Osteopontin Expression

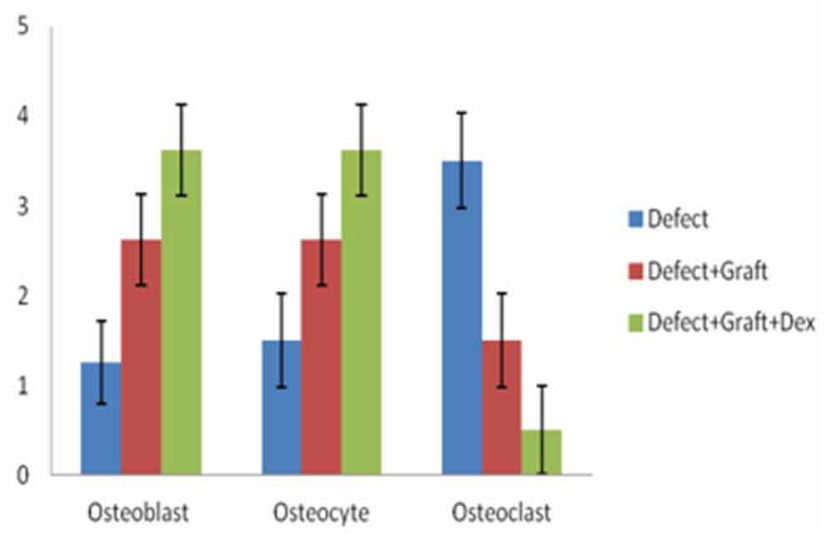

Fig. 1. Graphical view of expression levels of osteonectin and osteopontin. Immunohistochemical examination showed that osteonectin and osteopontin expression in osteoblasts and osteocytes were low in defect group but increased in graft group and dexamethasone treated group. The expression in osteoclast cells increased in the defect group but decreased in the graft group and dexamethasone group. This is statistically significant in terms of new bone formation.

ascending alcohol and cleared in xylene. Product Number: HHS32 SIGMA, Hematoxylin Solution, Harris Modified, Sigma-Aldrich, 3050 Spruce Street, Saint Louis, MO 63103, USA. Slides were mounted with Entellan ${ }^{\circledR}$ (lot: 107961, Sigma-Aldrich, St. Louis, MO, United States) and examined under light microscope (Zeiss, Germany).

Statistical analysis. The data in the study were evaluated as Arithmetic mean \pm Standard deviation. Statistical analyzes were done using SPSS program. Kruskal-Wallis test and Bonferroni corrected post-hoc test were used to compare the groups. $\mathrm{P}<0.05$ was taken as the level of significance.

\section{RESULTS}

All morphological changes in congestion of blood vessels, inflammation, new bone formation was detailly noted. The intensity of these changes was graded from 0 to 4 (Laçin et al., 2019).

Histopathological parameters of all groups were shown in Table I.

Inflammation and congestion in blood vessels were increased significantly in the defect and defect+graft groups (groups 1 and 2) compared to the defect + graft + dexamethasone (group 3 ) group $(\mathrm{p}=0)$. For the new bone formation, a significant increase was observed in defect+graft+dexamethasone group compared to defect and defect+graft groups $(\mathrm{p}=0)$.

Histopathological examination. Histopathological examination of tibia sections in defect group revealed dilatation and congestion in the blood vessels, increased inflammation, edema and osteoclastic activity in some areas. Osteoblast and osteocyte cells with pyknotic nuclei, dilatation in the Havers ducts and deterioration in the osteon structure were observed. In the defect + graft group, there was a decrease in osteoclast activity around the periphery of the compact bone. Increased osteoblastic activity cells and generation of osteocyte cells showed remodeling bone matrix. Reduced level of inflammation, vascular dilatation and congestion were also observed. In the defect+graft+dexamethasone group, decreased inflammation and vascular congestion and increased osteoblastic activity were observed. These are important matrix interactions indicating bone development. Increasing osteocyte differentiation with decreasing osteoclastic activity caused the formation of new bone trabeculae by accelerating the development of new bone, thus new bone formation started in the tibial defect area. Dexamethasone showed positive effect on osteocyte development and new bone formation by increasing osteoblast activity in 28 days.

\section{Immunohistochemical examinations}

Defect group: Osteonectin expression was positive in inflammatory cells and osteoclast cells within the defect area and in connective tissue fibers and some degenerated connective cells. Defect+graft group: Osteonectin was positively expressed in some connective tissue cells with mitotic activity and fibers in bone matrix, and in osteoblast cells at the periphery of the graft regions within the defect area. Defect+graft+dexamethasone group: Increased osteonectin expression in osteoblast and osteocyte cells in new developing bone trabeculae within the diminishing defect area. The osteonectin was expressed in osteon 
Table I. Comparison of all groups with Kruskal-Wallis and Bonferroni test. Data are expressed as the mean \pm standard deviation and mean rank ( $\mathrm{p}=0$ with Kruskal-Wallis test, and $* * \mathrm{p}<0.05$ with Bonferroni test $*$ and $* *$ statistically significant result).

\begin{tabular}{|c|c|c|c|c|c|c|}
\hline Parameter & Groups & $n$ & Mean $\pm S D$ & Mean Rank & $\begin{array}{l}\text { Kruskal- } \\
\text { Wallis } \\
\text { Test value }\end{array}$ & $\begin{array}{c}\text { Multiple } \\
\text { comparisons for } \\
\text { groups } \\
(p<0.05)\end{array}$ \\
\hline Osteonectin & (1) Defect & 8 & $0,75 \pm 0,46$ & 4,50 & \multirow{3}{*}{$\begin{array}{c}19,199 \\
P=0\end{array}$} & $(2)(3)$ \\
\hline \multirow[t]{2}{*}{ Expression } & (2) Defect+Graft & 8 & $2,62 \pm 0,51$ & 13,75 & & (1) \\
\hline & (3) Defect+Graft+Dexamethasone & 8 & $3,50 \pm 0,53$ & 19,25 & & (1) \\
\hline Osteonectin & (1) Defect & 8 & $1,12 \pm 0,46$ & 5,13 & \multirow{3}{*}{$\begin{array}{c}18,369 \\
P=0\end{array}$} & (3) \\
\hline \multirow{2}{*}{ Expression } & (2) Defect+Graft & 8 & $2,37 \pm 0,51$ & 12,63 & & \\
\hline & (3) Defect+Graft+Dexamethasone & 8 & $3,50 \pm 0,53$ & 19,75 & & (1) \\
\hline Osteonectin & (1) Defect & 8 & $3,37 \pm 0,51$ & 20,19 & \multirow{3}{*}{$\begin{array}{c}18,085 \\
P=0\end{array}$} & (2) (3) \\
\hline \multirow[t]{3}{*}{ Expression } & (2) Defect+Graft & 8 & $1,62 \pm 0,74$ & 11,31 & & (1) \\
\hline & (3) Defect+Graft+Dexamethasone & 8 & $0,75 \pm 0,46$ & 6,00 & & (1) \\
\hline & (1) Defect & 8 & $1,25 \pm 0,46$ & 4,88 & 18,621 & (2) (3) \\
\hline \multirow[t]{2}{*}{ OsteopontinExpression } & (2) Defect+Graft & 8 & $2,62 \pm 0,51$ & 13,06 & $P=0$ & (1) \\
\hline & (3) Defect+Graft+Dexamethasone & 8 & $3,62 \pm 0,51$ & 19,56 & \multirow{3}{*}{$\begin{array}{c}17,705 \\
P=0\end{array}$} & (1) \\
\hline Osteocyte & (1) Defect & 8 & $1,50 \pm 0,53$ & 5,25 & & (3) \\
\hline OsteopontinExpression & (2) Defect+Graft & 8 & $2,62 \pm 0,51$ & 12,69 & & \\
\hline & (3) Defect+Graft+Dexamethasone & 8 & $3,62 \pm 0,51$ & 19,56 & \multirow{4}{*}{$\begin{array}{c}19,279 \\
P=0\end{array}$} & (1) \\
\hline Osteopontin & (1) Defect & 8 & $3,50 \pm 0,53$ & 20,50 & & $(2)(3)$ \\
\hline \multirow[t]{2}{*}{ Expression } & (2) Defect+Graft & 8 & $1,50 \pm 0,53$ & 11,50 & & (1) \\
\hline & (3) Defect+Graft+Dexamethasone & 8 & $0,50 \pm 0,49$ & 5,50 & & (1) \\
\hline \multirow[t]{3}{*}{ Inflammation } & (1) Defect & 8 & $3,37 \pm 0,74$ & 19,19 & \multirow{3}{*}{$\begin{array}{c}17,642 \\
P=0\end{array}$} & (3) \\
\hline & (2) Defect+Graft & 8 & $2,37 \pm 0,51$ & 13,44 & & (3) \\
\hline & (3) Defect+Graft+Dexamethasone & 8 & $1,00 \pm 0,53$ & 4,88 & & $(1)(2)$ \\
\hline \multirow[t]{3}{*}{ Congestion blood vessels } & (1) Defect & 8 & $3,50 \pm 0,53$ & 18,50 & \multirow{3}{*}{$\begin{array}{c}17,616 \\
P=0\end{array}$} & (3) \\
\hline & (2) Defect+Graft & 8 & $2,87 \pm 0,64$ & 14,38 & & (3) \\
\hline & (3) Defect+Graft+Dexamethasone & 8 & $1,00 \pm 0,53$ & 4,63 & & $(1)(2)$ \\
\hline \multirow[t]{3}{*}{ New formation } & (1) Defect & 8 & $1,12 \pm 0,64$ & 5,56 & \multirow{3}{*}{$\begin{array}{c}16,841 \\
P=0\end{array}$} & (3) \\
\hline & (2) Defect+Graft & 8 & $2,25 \pm 0,70$ & 12,38 & & \\
\hline & (3) Defect+Graft+Dexamethasone & 8 & $3,37 \pm 0,50$ & 19,56 & & (1) \\
\hline
\end{tabular}

structures within the newly developing bone. In the defect group, osteopontin expression was positive in inflammatory cells, osteoclast cells and degenerated connective tissue cells and fibers. In the defect+graft group, osteoblast cells in small bone trabeculae with osteoinductive activity showed osteopontin expression in the graft area within the defect area. Osteopontin reaction was detected in connective tissue cells and fibers in the graft region where the new bone formation started. In the group with graft+dexamethasone, since osteon formation developed in the newly bone trabeculae with increased osteoblastic activity and osteocyte cells, osteopontin expression was increased in the osteoblast and osteocyte cells.

\section{DISCUSSION}

Graft materials used to prevent damage caused by bone defects affect the development of osteocyte and bone trabeculae by inducing osteoblastic activity. Some researchers showed that experimental bone injury with induced many osseous interactions because of biomaterial used in rat tibial bone and used for the evaluation of bone healing. Bone grafts are often required to provide support, fill gaps and improve biological repair in skeletal damage (Melo et al., 2005; Ribeiro et al., 2008). Different bone graft materials have been used for bone regeneration, closure of osteotomy openings, and alveolar augmentation in oral and maxillofacial surgeons (Beirne, 1986; Byrd et al., 1993). Natural coral-derived grafts and synthetic bone graft materials are used in alveolar crest elevation, intra bone defects, material loss fractures, facial bone defects, orthognathic surgery, and maxillary sinus ground (Page \& Laksin, 1987; Corsair, 1990; Byrd et al.). Alloplastic bone grafts are synthetic, inorganic, biocompatible, and bioactive bone substitutions which are believed to repair bone defects through osteoconduction. Allografts are used freeze-dried demineralized bone allograft (FDBA) and demineralized freeze-dried bone allograft form known as (DFDBA) (Salyer 

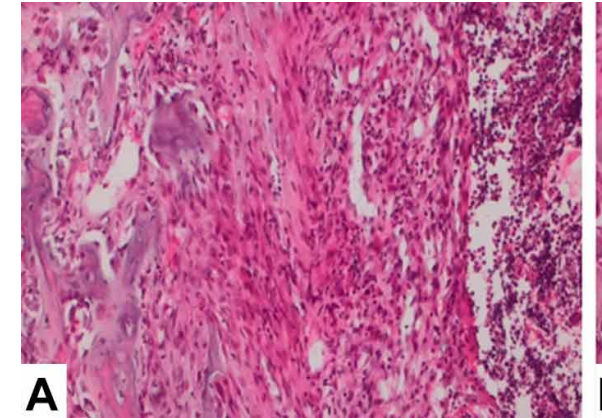
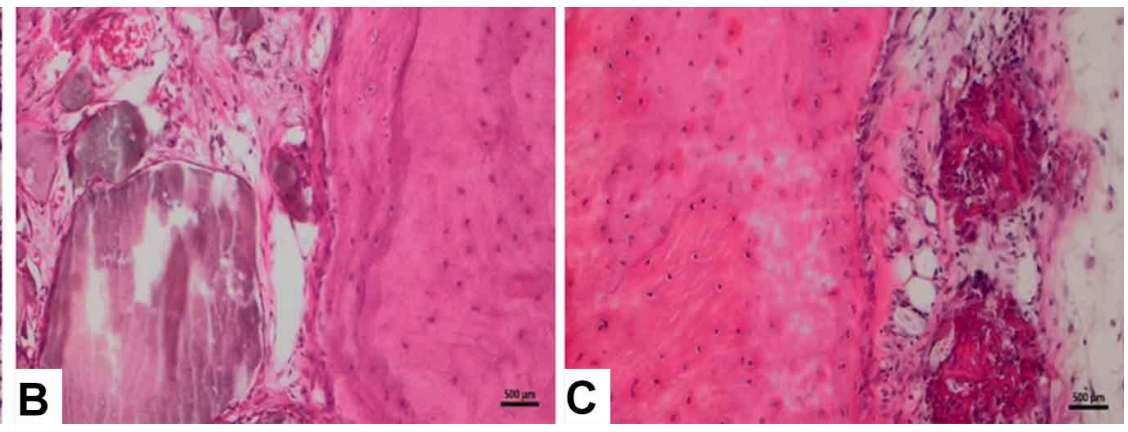

Fig. 2. A. Defect group: Increased inflammation within the defect area, vascular dilatation and congestion, degenerated intensive cell infiltration, Hematoxylin-Eosin. B. Defect+graft group; Bone matrix development around the graft areas, decreased inflammation and osteoclast cells, Hematoxylin-Eosin. C. Defect+graft+dexamethasone group; increased osteoblast cells, generation of osteocyte cells and dense bone matrix, formation of new bone trabeculae, Hematoxylin-Eosin staining.

et al., 1995). Wang et al. (2017) suggested that lactic-glycolic acid- alendronate may be a potential bone graft substitute to enhance bone repair in a rat femoral bone defect model. It was also reported that alendronate enhanced the new bone formation by autogenous bone graft in the rat calvarial defect model. Bone remodeling is a constant and dynamic process
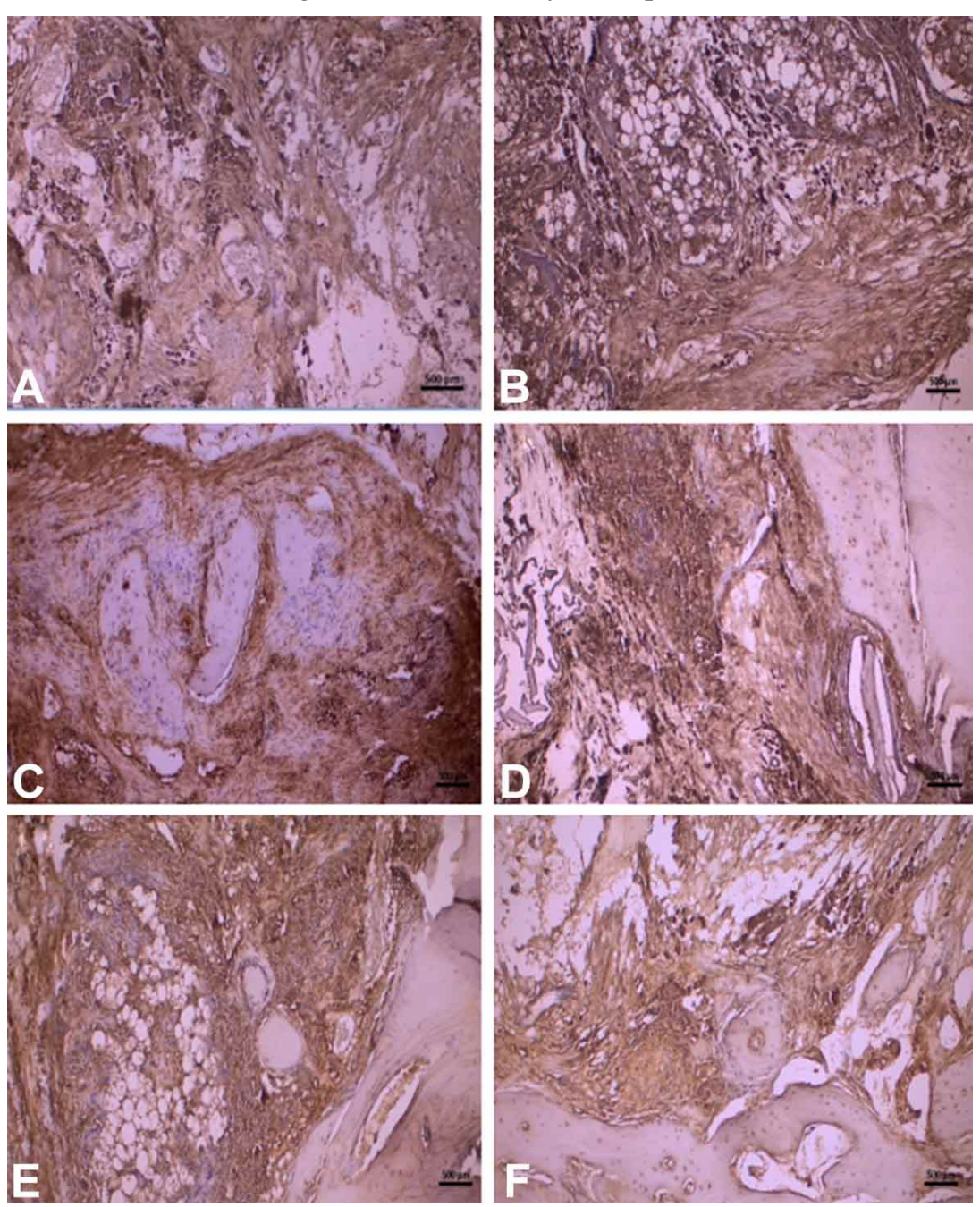

in which osteoclasts resorb old bone and osteoblasts form new bone. In a study by Laçin \& Deveci (2019) showed that allograft material prevented callus development, causing increased collagen activity in the connective tissue and increased osteoinductive effect. They reported that the inductive effect of osteogenic cells accelerated the development of invasive osteoblast cells, leading to the development of matrix and osteoblast cells in new bone formation. In our study, we observed that the allograft material stimulated the osteoinduction phase, causing the generation of osteoprogenitor cells, the initiation of osteoblastic activity, decreased inflammation and the reduction of necrotic area (Fig. 2).

Fig. 3. A. Defect group: Positive osteonectin expression in inflammatory cells and osteoclast cells, osteonectin immune staining. B. Defect+Graft group; positive osteonectin expression in the periphery of the graft regions, osteoblast cells, some connective tissue cells and fibers, Osteonectin immune staining. C. Defect+Graft+Dexamethasone group; An increase in osteonectin expression in osteoblast and osteocyte cells in new bone trabeculae, Osteonectin immune staining. D. Defect group; Osteopontin expression positive in cells and osteoclast cells within the area of inflammation, Osteopontin immune staining. E. Defect+Graft group; Positive osteopontin expression in osteoblast cells in small bone trabeculae, Osteopontin immune staining. F. Defect+Graft+Dexamethasone group; Positive osteopontin expression in osteoblast and osteocyte cells in new bone trabeculae, Osteopontin immune staining. 
Dex is a synthetic glucocorticoid which has been shown to induce in vitro osteogenesis of stem cells in combination with ascorbic acid and beta-glycerol phosphate (Vater et al., 2011). A study showed that the defect area healed in 8 weeks after the rat was implanted with a defect of $60 \%$ Hydroxy Apatite (HA). In addition, the amount of regeneration was significantly higher in animals given Dex / HA compared to control animals. Dex was shown to accelerate the bone healing effect of Hydroxy Apatite in rat calvarial defects. Some studies stated that the use of different biomaterials with Dex may be an effective in bone regeneration after the defect formation (Tavakoli-Darestani et al., 2014). In our study, the increase of osteocyte differentiation with decrease of osteoclastic activity at the end of 28 days accelerates the new bone development and the formation of bone trabeculae and explains the osteoinductive effect of Dexametazon with the graft. Osteonectin is a protein known to be involved in cell-matrix interactions, angiogenesis and important for normal ossification (Koparal et al., 2016). Osteonectin is secreted by osteoblast cells during bone formation. Osteopontin is expressed in bone and is thought to control the growth of mineral crystals (Suda, 2007). Osteopontin (OPN) is a noncollagenous matrix protein. OPN is known to play a role in cell adhesion, migration, survival, and bone remodeling (Al-Shami et al., 2005). Research in animal models indicates that OPN deficiency alters the functionality of multiple cell types, resulting in delayed early vascularization, altered matrix organization, and late bone remodeling. Baloglu \& Deveci reported that they induced bone matrix development in rats with clomiphene citrate after ovariectomy and induced new bone formation with increased osteonectin and osteopontin expression. Research in different animal models shows that OPN deficiency changes the functionality of multiple cell types, delayed early vascularization, altered matrix organization and causes late bone remodeling (Duvall et al., 2007). In our study, expression of osteopontin and osteonectin was positive in some inflammatory cells and osteoclast cells in the defect region. Because small bone trabeculae in the graft group were formed, osteoblasts and some osteocytes showed a positive osteonectin and osteopontin expression (Fig. 3). In the Dex-treated group, bone trabeculae grew larger, and osteonectin and osteopontin expression increased significantly in osteoblast osteocytes in the region of bone matrix was dense.

Considering osteonectin, an extracellular matrix glycoprotein, is an indicator of osteogenic development, it increases in osteoblast cells, while osteopontin with high hydroxyapatite affinity forms a bridge between bone cells by osteoconductive and osteoinductive effect.
It has been thought that the effect of Dexamethasone in the graft region with the influence of osteoprogenitor cells may lead to formation of new bone trabeculae into the graft material by increasing activity of osteoblast cells and osteonectin protein synthesis, resulting increased osteoconduction and osteoinductive effect for differentiation of osteon.

YIGIT, S. \& DEVECI, E. Aplicación de injerto y tratamiento con dexametasona influyen en la formación de hueso nuevo en los defectos en tibia de rata. Int. J. Morphol., 38(5):1398-1404, 2020.

RESUMEN: Los defectos óseos son complicaciones que ocurren debido a traumas o infecciones. Se requieren injertos óseos para proporcionar apoyo, llenar los espacios y mejorar la reparación biológica en el hueso dañado. La dexametasona desempeña un papel importante en la modulación de la señalización del calcio y se usa en enfermedades. El objetivo de este estudio fue evaluar las expresiones de osteonectina y osteopontina en el desarrollo óseo después de la aplicación de dexametasona en defectos óseos tibiales. Las ratas se dividieron en grupos: defecto, defecto + injerto y defecto + injerto + grupos tratados con dexametasona. Se creó un defecto óseo tibial, y las ratas se mantuvieron inmóviles durante 28 días. El material aloplástico se colocó en el área del defecto en el segundo y tercer grupo. Se inyectaron $2,5 \mathrm{mg} / \mathrm{kg}$ de dexametasona y solución salina normal a grupos de defectos dos veces por semana durante 56 días. La inflamación y la congestión aumentaron en los grupos de defectos y defectos + injerto; En el grupo defecto + injerto + grupo tratado con dexametasona se observó un aumento en el número de osteoblastos y osteocitos, de matriz ósea densa y en la formación de nuevas trabéculas óseas. En el grupo defecto + grupo de injerto se observó la expresión de osteonectina en las áreas de injerto, osteoblastos, algunas células y fibras de tejido conectivo, mientras que en el grupo defecto + injerto + dexametasona se observó la expresión de osteopontina en osteoblastos y osteocitos y formación de nuevas trabéculas óseas . En conclusión la dexametasona puede conducir a la formación de nuevas trabéculas óseas en el material de injerto, lo que resulta en un aumento de la osteoconducción y un efecto osteoinductivo para la diferenciación del osteón.

PALABRAS CLAVE: Defectos óseos; Bioinjerto; Dexametasona; Osteonectina; Osteopontina.

\section{REFERENCES}

Al-Shami, R.; Sorensen, E. S.; Ek-Rylander, B.; Andersson, G.; Carson, D. D. \& Farach-Carson, M. C. Phosphorylated osteopontin promotes migration of human choriocarcinoma cells via a p70 S6 kinasedependent pathway. J. Cell. Biochem., 94(6):1218-33, 2005.

Baloglu, M. \& Deveci, E. Effects of clomiphene citrate on bone damage in the tibial bones of ovariectomized rats. Anal. Quant. Cytol. Histol., 40:213-21, 2018

Beirne, O. R. Comparison of complications after bone removal from lateral and medial plates of the anterior ileum for mandibular augmentation. Int. J. Oral Maxillofac. Surg., 15(3):269-72, 1986. 
Byrd, H. S.; Hobar, P. C. \& Shewmake, K. Augmentation of the craniofacial skeleton with porous hydroxyapatite granules. Plast. Reconstr. Surg., 91(1):15-22, 1993.

Corsair, A. A clinical evaluation of resorbable hydroxylapatite for the repair of human intra-osseous defects. J. Oral Implantol., 16(2):125-8, 1990.

Cui, Y.; Niziolek, P. J.; MacDonald, B. T.; Zylstra, C. R.; Alenina, N.; Robinson, D. R.; Zhong, Z.; Matthes, S.; Jacobsen, C. M.; Conlon, R. A.; et al. Lrp5 functions in bone to regulate bone mass. Nat. Med., 17(6):684-91, 2011.

Dallas, S. L. Dynamics of bone extracellular matrix assembly and mineralization. J. Musculoskelet. Neuronal Interact., 6(4):370-1, 2006.

Denhardt, D. T. \& Noda, M. Osteopontin expression and function: role in bone remodeling. J. Cell. Biochem. Suppl., 30-31:92-102, 1998.

Duvall, C. L.; Taylor, W. R.; Weiss, D.; Wojtowicz, A. M. \& Guldberg, R. E. Impaired angiogenesis, early callus formation, and late stage remodeling in fracture healing of osteopontin-deficient mice. J. Bone Miner. Res., 22(2):286-97, 2007.

Koparal, M.; Irtegün, S.; Alan, H.; Deveci, E.; Gülsün, B. \& Pektanç, G. Effects of melatonin on tibia bone defects in rats Int. J. Morphol., 34(2):763-9, 2016.

Laçin, N. \& Deveci, E. Short-term use of resveratrol in alloplastic graft material applied with calvarial bone defects in rats. Acta Cir. Bras., 34(7):e201900704, 2019.

Laçin, N.; Izol, B. S.; Özkorkmaz, E. G.; Deveci, B. \& Tuncer, M. C. The effect of graft application and simvastatin treatment on tibial bone defect in rats. A histological and immunohistochemical study. Acta Cir. Bras., 34(4):e201900408, 2019.

Melo, L. G. N.; Nagata, M. J. H.; Bosco, A. F.; Ribeiro, L. L. G. \& Leite, C. M. Bone healing in surgically created defects treated with either bioactive glass particles, a calcium sulfate barrier, or a combination of both materials. a histological and histometric study in rat tibias. Clin. Oral Implants Res., 1686):683-91, 2005.

Page, D. G. \& Laksin, D. M. Tissue response at the bone-implant interface in a hydroxylapatite augmented mandibular ridge. J. Oral Maxillofac. Surg., 45(4):356-8, 1987.

Ribeiro, L. L. G.; Bosco, A. F.; Nagata, M. J. H. \& de Melo, L. G. N. Influence of bioactive glass and/or acellular dermal matrix on bone healing of surgically created defects in rat tibiae: a histological and histometric study. Int. J. Oral Maxillofac. Implants, 23(5):811-7, 2008.

Roberts, T. T. \& Rosenbaum, A. J. Bone grafts, bone substitutes and orthobiologics. The bridge between basic science and clinical advancements in fracture healing. Organogenesis, 8(4):114-24, 2012.

Salyer, K. E.; Bardach, J.; Squier, C. A.; Gendler, E. \& Kelly, K. M. Cranioplasty in the growing canine skull using demineralized perforated bone. Plast. Reconstr. Surg., 96(4):770-9, 1995.

Shredah, M. \& Abd-Nasser, A. E. Immunohistochemical expression of transforming growth factor -b in bone regeneration in rats after application of simvastatin. Int. J. Adv. Res. Biol. Sci., 2(6):129-41, 2015.

Suda, T. Mechanism of Calcification. In: Suda, T.; Ozawa, E.; Takahashi, H.; Tanaka, S.; Nakamura, H. \& Mori, S. (Eds.). Bone Biology. Tokyo, Ishiyaku Publishers, 2007. pp.145-64.

Tavakoli-Darestani, R.; Manafi-Rasi, A. \& Kamrani-Rad, A. Dexamethasone-loaded hydroxyapatite enhances bone regeneration in rat calvarial defects. Mol. Biol. Rep., 41(1):423-8, 2014.

Vater, C.; Kasten, P. \& Stiehler, M. Culture media for the differentiation of mesenchymal stromal cells. Acta Biomater., 7(2):463-77, 2011.

Wang, Y. H.; Rajalakshmanan, E.; Wang, C. K.; Chen, C. H.; Fu, Y. C.; Tsai, T. L.; Chang, J. K. \& Ho, M. L. PLGA-linked alendronate enhances bone repair in diaphysis defect model. J. Tissue Eng. Regen. Med., 11(9):2603-12, 2017.

Weiler, H. A.; Wang, Z. \& Atkinson, S. A. Dexamethasone treatment impairs calcium regulation and reduces bone mineralization in infant pigs. Am. J. Clin. Nutr., 61(4):805-11, 1995.

Young, M. F.; Kerr, J. M.; Ibaraki, K.; Heegaard, A. M. \& Robey, P. G. Structure, expression, and regulation of the major noncollagenous matrix proteins of bone. Clin. Orthop. Relat. Res., (281):275-94, 1992.
Corresponding author: Engin Deveci, Chief Editor Department of Histology and Embryology Faculty of Medicine University of Dicle 21280, Diyarbakır TURKEY

Email: devecie@mynet.com

Received: 08-04-2020

Accepted: $31-05-2020$ 